\title{
Walking as an intervention during chemotherapy: integrative review
}

\section{A caminhada como intervenção durante a quimioterapia: revisão integrativa La caminata como intervención durante la quimioterapia: revisión integradora}

Carla Sílvia Fernandes*; Bruno Miguel Borges de Sousa Magalhães**; Célia de Brito Santos**; Juan Miguel Martínez Galiano****

\begin{abstract}
Background: Walking has been used as a health promotion and symptom relief intervention in patients with cancer during chemotherapy.

Objective: To map the existing literature on the use of walking as an intervention in patients undergoing chemotherapy.

Methodology: Integrative review of articles found in MEDLINE ${ }^{\circledR}$ and CINAHL ${ }^{\circledR}$ databases. The review protocol was designed and the thematic categorization was performed.

Results: Based on inclusion and exclusion criteria, 12 primary studies published between 2010 and 2017 were considered for analysis. Five relevant thematic areas were identified: duration, frequency, and monitoring of walking during chemotherapy; adherence to the walking intervention; effects on psychological and physical symptoms; target population; and assessment tools.

Conclusion: Despite the advantages of the walking intervention during chemotherapy, evidence on its use as a nursing intervention is still scarce, with further research being required in this area.
\end{abstract}

Keywords: walking; chemotherapy; neoplasms; exercise

\section{Resumo}

Enquadramento: A caminhada tem vindo a ser utilizada como intervenção promotora da saúde e para alívio dos sintomas em utentes com cancro durante a quimioterapia.

Objetivo: Delineou-se este percurso com o objetivo de mapear a produçáo científica sobre a utilização da caminhada enquanto intervenção nos utentes sujeitos a quimioterapia.

Metodologia: Procedeu-se a uma revisão integrativa da literatura de artigos das bases de dados MEDLINE ${ }^{\circledR} \mathrm{e}$ CINAHL $^{\circledR}$. O protocolo de revisão foi elaborado e a categorizaçáo temática foi realizada.

Resultados: Com base nos critérios de inclusão e exclusão, foram considerados 12 estudos primários para análise, publicados entre 2010 e 2017. Foram identificadas 5 áreas temáticas relevantes: duração, frequência e acompanhamento da caminhada durante a quimioterapia, adesão à intervenção da caminhada, efeitos nos sintomas psicológicos e físicos, população-alvo e instrumentos de avaliação utilizados.

Conclusáo: Apesar das vantagens da utilização da caminhada durante a quimioterapia, é ainda incipiente a sua utilização como intervenção de enfermagem, sendo fundamental mais investigação a este nível.

Palavras-chave: caminhada; quimioterapia; neoplasias; exercício

*Ph.D., Assistant Professor, University Fernando Pessoa, School of Health, 4200-150, Porto, Portugal [carlasilviaf@gmail.com].Contribution to the article: analysis of the literature search and article writing. Address for correspondence: Rua do Cidral no 28, 4490-562, Póvoa do Varzim, Portugal.

**MSc., Adjunct Professor, Santa Maria Health School, 4049-024, Porto, Portugal [bruno.magalhaes@ santamariasaude.pt]. Contribution to the article: analysis of the literature search and article revision. ****Ph.D., Coordinating Professor, Nursing School of Porto, 4200-072, Porto, Portugal [celiasantos@ esenf.pt]. Contribution to the article: analysis of the literature search and article revision. ****Ph.D., Professor, University of Jaén, 23071, Jaén, Spain [jgaliano@ujaen.es]. Contribution to the article: article revision.

\section{Resumen}

Marco contextual: La caminata se ha utilizado como intervención para promover la salud y aliviar los síntomas durante la quimioterapia en los pacientes con cáncer.

Objetivo: Se desarrolló este itinerario con el objetivo de mapear la producción científica sobre la utilización de la caminata como intervención en los usuarios sometidos a quimioterapia.

Metodología: Se realizó una revisión integradora de la literatura de artículos de las bases de datos MEDLINE ${ }^{\circledR}$ y CINAHL $^{\circledR}$. El protocolo de revisión se diseñó y se realizó la categorización temática.

Resultados: Con base en los criterios de inclusión y exclusión, se consideraron para su análisis 12 estudios primarios publicados entre 2010 y 2017 . Se identificaron 5 áreas temáticas relevantes: duración, frecuencia y seguimiento de la caminata durante la quimioterapia, adhesión a la intervención de la caminata, efectos en los síntomas psicológicos y físicos, población objetivo e instrumentos de evaluación utilizados.

Conclusión: A pesar de las ventajas de la utilización de la caminata durante la quimioterapia, su utilización como intervención de enfermería es aún incipiente, por lo que es fundamental realizar más investigaciones a este nivel.

Palabras clave: caminata; quimioterapia; neoplasias; ejercicio

Received for publication: 30.08 .17

Accepted for publication: 05.12 .17

Série IV - 1. ${ }^{\circ} 17$ - ABR./MAI.JUUN. 2018 


\section{Introduction}

Although there has been considerable progress in reducing cancer incidence (Siegel et al., 2012), cancer is still responsible for one in three premature deaths worldwide (Bray, 2016). The increase in the number of individuals diagnosed with cancer each year, due to the aging and growth of the population, as well improvements in survival rates, will lead to an increasing number of cancer survivors (Siegel et al., 2012). However, the course of cancer has changed from a diagnosis of anticipated death to a concept of chronic disease (Peixoto, Peixoto, Santos, \& Pinto, 2016), which is associated with a sequence of aggressive treatments with significant side effects. Cancer patients can experience a large number of symptoms due to both treatment and progression of the disease, including fatigue, lack of energy, difficulty breathing, pain, anxiety, depression, and problems sleeping (Bennion \& Molassiotis, 2013). Many of these symptoms are associated with chemotherapy treatments, particularly the most commonly reported symptoms such as nausea, vomiting, hair loss, and fatigue (Wagland et al., 2015), as well as emotional consequences of anxiety and family burden (Sasaki et al., 2017). As a result, it is increasingly important to integrate the resources that can assist patients, caregivers, and health care providers in navigating the various phases of cancer survivorship (Siegel et al., 2012). The multiplicity and complexity of symptoms in patients treated with chemotherapy require multifaceted symptom management interventions (Coolbrandt et al., 2014). Several interventions can be used to help the patient cope with the symptoms, including teaching sessions, psychotherapy, behavioral therapy, and physical exercise (Coolbrandt et al., 2014). Exercise interventions and increased physical activity are a promising way of counteracting the multiplicity of symptoms (Zimmer et al., 2016). Meneses-Echávez, González-Jiménez, Correa-Bautista, Río, and Ramírez-Vélez (2015) underline that exercise is a safe and effective intervention for fatigue management in cancer patients undergoing active treatment. However, Zimmer et al. (2016) highlight some methodological constraints, particularly the heterogeneity of assessments and interventions, as well as the lack of adequate control groups. Studies using phys- ical activity interventions during chemotherapy adopt several strategies, namely regarding the type of exercises, duration, and implementation, self-managed or supervised interventions (Meneses-Echávez et al., 2015). On the other hand, some of these interventions are not likely scalable to the majority of cancer patients because they are expensive, require substantial skills and equipment, and are usually only available in large metropolitan areas (Vallance et al., 2016). According to Sung and Bae (2012), walking is the most described exercise in the literature, with many advantages in its application. Walking is a simple, less costly intervention for cancer patients, which can be self-managed and introduced on a large scale (Gokal et al., 2016). Cancer nurses should promote exercise as a wellness-fostering intervention during the chemotherapy treatment (Husebø, Allan, Karlsen, Søreide, \& Bru, 2015). Aware of the potential benefits that could arise from a simple intervention such as walking, an integrative literature review was conducted with the purpose of mapping the existing evidence on the use of walking as an intervention for patients undergoing chemotherapy. The results of this review can provide nursing professionals with a deeper knowledge for the development of interventions with simple exercises such as walking. This study aims to answer the following review question: How is walking used as an intervention in adult patients undergoing chemotherapy?

\section{Methodological integrative review procedures}

Taking into account the research question and the objectives set out, an integrative review was conducted following the steps recommended by the Joanna Briggs Institute (JBI, 2014). The formulation of the question was based on the population, concept, and context strategy (JBI, 2014). The search was performed during August 2017. As shown in Table 1, this review included studies with individuals aged 18 years or over, diagnosed with cancer, irrespective of the anatomical site, undergoing active chemotherapy, integrating an intervention with a walking exercise during chemotherapy. It also included primary studies which assessed outcomes related to symptoms or health behaviors and were published in English. 
Table 1

\section{Inclusion criteria}

\begin{tabular}{lll}
\hline Population & Concept & Context \\
\hline $\begin{array}{l}\text { Studies with adults, aged 18 years or } \\
\text { over, with cancer. }\end{array}$ & $\begin{array}{l}\text { Studies which address walking as } \\
\text { an intervention during chemo- } \\
\text { therapy. }\end{array}$ & $\begin{array}{l}\text { Studies in which the participants are } \\
\text { only undergoing chemotherapy; No } \\
\text { geographical or racial restrictions. }\end{array}$
\end{tabular}

Type of study: Primary studies.

The search was conducted independently by two researchers. It aimed to identify all articles published until June 2017 in the MEDLINE ${ }^{\oplus}$ and $\mathrm{CINAHL}^{\oplus}$ online databases. The following descriptors were used: cancer patient, chemotherapy, adjuvant, and walking. The study selection process involved several steps. The first step consisted of reading the titles of the articles identified in the search with the aim of excluding those that did not meet the inclusion criteria. Then, the studies were screened for eligibility based on abstract reading and those which were incomplete or raised doubts were excluded. Finally, the study selection process included fulltext reading. A total of 12 studies were included for analysis. This process was carried out by the researchers, independently, and the final result was obtained after consensus meeting. In order to systematize the data extracted from the studies, they were compiled in descriptive tables.

\section{Results and interpretation}

A total of 651 articles were initially retrieved, of which 110 were duplicates. The sample was then composed of 541 articles, of which 181 articles were included after title reading. Of these, 130 articles were excluded and 51 articles were proposed for full-text reading, of which 39 were excluded. Twelve articles were included for final analysis (Figure 1).
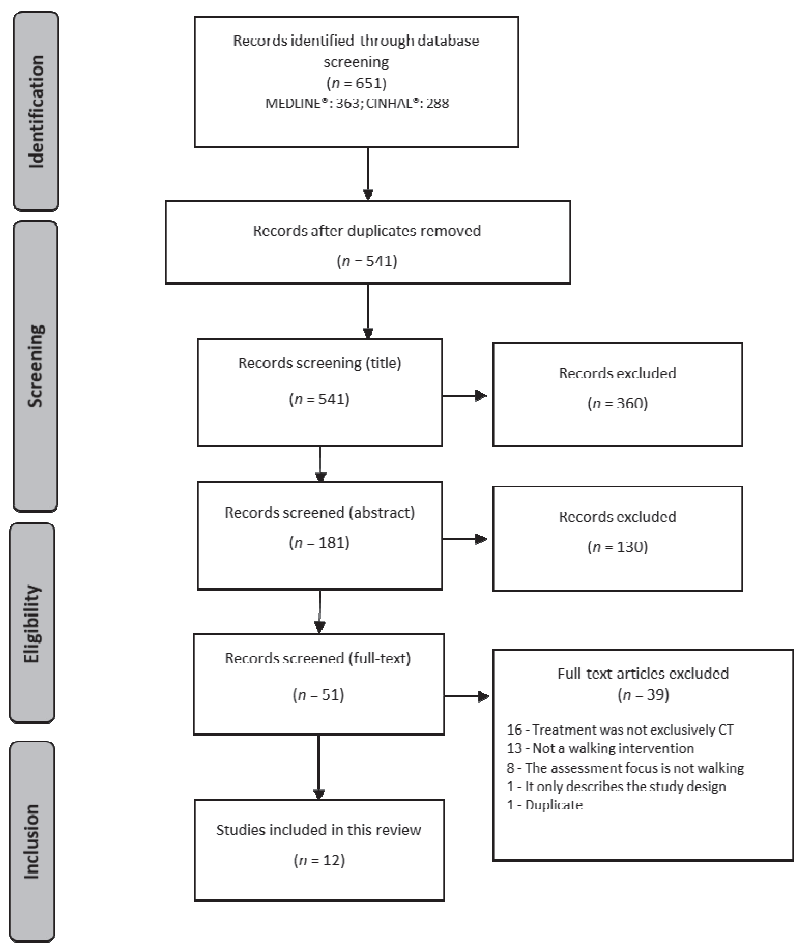

Figure 1. Study identification and inclusion process - PRISMA Diagram flow. 
Table 2 summarizes the studies included in this review, including information on the authors, year of publication, setting, main objectives, study design, and participants. It should be emphasized that, although the search had no time restrictions, the period of publication in the initial results was 40 years (1977-2017). However, the articles included in this review were published in recent years. A higher incidence was observed in 2015, with four articles, followed by 2016 and 2011, with two articles, and 2014, 2013, and 2010 with an article in each year. With regard to study setting, a wide geographical dispersion was found - two were published in the United States of America, two in Taiwan, and one in each of the following countries: Canada, Australia, South Korea, Thailand, England, Norway, France, and Sweden.

The articles included in this integrative review are mostly quantitative studies $(n=11)$, with most of them being clinical trials. It should be noted that 10 studies included patients with breast cancer, only one study included patients with breast and colorectal cancer (Backman et al., 2014), and another study included patients with ovarian cancer (Newton et al., 2011). Similar results were found in review studies on physical activity in cancer patients (Zimmer et al., 2016; Meneses-Echávez al., 2015; Jacobsen, Donovan, Vadaparampil, \& Small, 2007). With regard to the study objectives, they ranged from the assessment of the adherence to the physical activity intervention ( $\mathrm{S} 1$, $S 5, S 8, S 12)$ to the assessment of the physical (S3, S4, S6, S11) and psychological impact (S2, S3, S4, S10, S11) of the intervention or more specific aspects, such as maximal oxygen uptake (S6, S9), hemoglobin (S6), inflammatory markers (S6), and immune system (S7).

Table 2

Summary of the studies included in this integrative review

Code Study/ArticleRef $\quad$ Country Study objective Study design Participants

Vallance, J. K., Friedenreich, C. M., Lavallee, C. M., Culos-Reed, N., Mackey, J. R., Walley, B., \& Courneya, K. S. (2016). Exploring the feasibility of a broad-reach physical activity behavior

S1 change intervention for women receiving chemotherapy for breast cancer: a randomized trial. Cancer Epidemiology, Biomarkers \& Prevention, 25(2), 391398. doi:10.1158/1055-9965.EPI-150812

Gokal, K., Wallis, D., Ahmed, S., Boiangiu, I., Kancherla, K., \& Munir, F. (2016). Effects of a self-managed home-based walking intervention 2 on psychosocial health outcomes for breast cancer patients receiving chemotherapy: a randomised controlled trial. Supportive Care In Cancer, 24(3), 1139-1166. doi:10.1007/s00520-0152884-5

Naraphong, W., Lane, A., Schafer, J., Whitmer, K., \& Wilson, B. R. A. (2015). Exercise intervention for fa-

S3 tigue-related symptoms in Thai wom- Thailand en with breast cancer: A pilot study. Nursing \& Health Sciences, 17(1), 3341. doi:10.1111/nhs. 12124
To examine the effects of a physical activity intervention in changing physical Canada activity adherence behaviors in women with breast cancer undergoing chemotherapy.
Brest cancer

Randomized clinical trial with control group 46 control group 49 intervention group

\begin{tabular}{|c|c|c|c|}
\hline England & $\begin{array}{l}\text { To evaluate the effective- } \\
\text { ness of a self-managed } \\
\text { home-based moderate } \\
\text { intensity intervention on } \\
\text { psychosocial health out- } \\
\text { comes among breast can- } \\
\text { cer patients undergoing } \\
\text { chemotherapy. }\end{array}$ & $\begin{array}{c}\text { Randomized } \\
\text { clinical trial } \\
\text { with control } \\
\text { group }\end{array}$ & $\begin{array}{l}\text { Breast cancer } \\
25 \text { control } \\
\text { group } \\
25 \\
\text { intervention } \\
\text { group }\end{array}$ \\
\hline Thailand & $\begin{array}{l}\text { To examine the effects } \\
\text { of an exercise program } \\
\text { on fatigue, sleep dis- } \\
\text { turbance, mood distur- } \\
\text { bance, symptom distress, } \\
\text { and physical fitness for } \\
\text { Thai women with breast } \\
\text { cancer. }\end{array}$ & $\begin{array}{l}\text { Randomized } \\
\text { clinical trial } \\
\text { with control } \\
\text { group }\end{array}$ & $\begin{array}{c}\text { Brest cancer } \\
12 \text { control } \\
\text { group } \\
11 \\
\text { intervention } \\
\text { group }\end{array}$ \\
\hline
\end{tabular}


Husebø, A. M. L., Allan, H., Karlsen, B., Søreide, J. A., \& Bru, E. (2015). Exercise: a path to well-

S4 ness during adjuvant chemotherapy Norway

for Breast Cancer? Cancer Nursing, 38(5), E13-20. doi:10.1097/ NCC.0000000000000205

Huang, H.-P., Wen, F.-H., Tsai, J.-C., Lin, Y.-C., Shun, S.-C., Chang, H.-K., ... Chen, M.-L. (2015). Adherence to prescribed exercise time and intensity

S5 declines as the exercise program proceeds: findings from women under treatment for breast cancer. Supportive Care In Cancer, 23(7), 2061-2071. doi:10.1007/s00520-014-2567-7

Al-Majid, S., Wilson, L. D., Rakovski, C., \& Coburn, J. W. (2015). Effects of exercise on biobehavioral outcomes

S6 of fatigue during cancer treatment: results of a feasibility study. Biological Research For Nursing, 17(1),40-48. doi:10.1177/1099800414523489 California and impact on hemoglolife, and inflammatory markers.

Kim, J. J., Shin, Y. A., \& Suk, M. H. (2015). Effect of a 12-week walking exercise program on body composition and immune cell count in

S7 patients with breast cancer who are undergoing chemotherapy. Journal Of Exercise Nutrition \& Biochemistry, 19(3), 255-262. doi:10.5717/ jenb.2015.15092812

Backman, M., Wengström, Y., Johansson, B., Sköldengen, I., Börjesson, S., Tärnbro, S., \& Berglund, Å. (2014). A randomized pilot study

S8 with daily walking during adjuvant chemotherapy for patients with breast and colorectal cancer. Acta Oncologica, 53(4), 510-520. doi:10.3109/028 4186X.2013.873820

Vincent, F., Labourey, J. L., Leobon, S., Antonini, M. T., Lavau-Denes, S., \& Tubiana-Mathieu, N. (2013). Effects of a home-based walking training program on cardiorespiratory fit-

S9 ness in breast cancer patients receiving adjuvant chemotherapy: a pilot study. European Journal Of Physical And Rehabilitation Medicine, 49(3), 319329. Retrieved from https://www. ncbi.nlm.nih.gov/pubmed/23480974
To describe how exercise is perceived by women to influence their physical and psychosocial wellness at the time they were receiving chemotherapy. of exercise adherence and its predictors for women with breast cancer during chemotherapy.
To examine the effect of a 12-week walking exercise program on body composition and immune cell count in patients with breast cancer who are undergoing chemotherapy.
To study feasibility and adherence of a physical activity intervention among patients with cancer during chemotherapy treatment.
To investigate the effects of a 12-week home-based walking training program on the respiratory rehabilitation of patients with breast cancer undergoing chemotherapy.
Descriptive and exploratory study with focus groups
Brest cancer 25 focus groups
Brest cancer

Randomized 78 control clinical trial group with control group

$$
81
$$

intervention group bin, aerobic fitness (VO$2 \max$ ), fatigue, quality of

To determine the feasibility of conducting an exercise intervention among women receiving treat-

Randomized clinical trial with control group

Brest cancer 7 control group 7 intervention group
Experimental study without randomization or control group
Brest cancer 20 intervention group
Breast and colorectal Randomized cancer clinical trial 35 with control intervention group

group 36 control group
Experimental study without randomization or control group
Brest cancer 34 intervention group 


\begin{tabular}{|c|c|c|c|c|c|}
\hline S10 & $\begin{array}{l}\text { Yang, C., Tsai, J., Huang, Y., \& Lin, C. } \\
\text { (2011). Effects of a home-based walk- } \\
\text { ing program on perceived symptom } \\
\text { and mood status in postoperative breast } \\
\text { cancer women receiving adjuvant } \\
\text { chemotherapy. Journal Of Advanced } \\
\text { Nursing, 67(1), 158-168. doi:10.1111/ } \\
\text { j.1365-2648.2010.05492.x }\end{array}$ & Taiwan & $\begin{array}{l}\text { To analyze the effect of a } \\
\text { home-based walking exer- } \\
\text { cise program on mood dis- } \\
\text { tress among breast cancer } \\
\text { women receiving chemo- } \\
\text { therapy postoperatively. }\end{array}$ & $\begin{array}{l}\text { Randomized } \\
\text { clinical trial } \\
\text { with control } \\
\text { group }\end{array}$ & $\begin{array}{l}\text { Brest cancer } \\
19 \text { interven- } \\
\text { tion group } \\
19 \text { control } \\
\text { group }\end{array}$ \\
\hline S11 & $\begin{array}{l}\text { Newton, M. J., Hayes, S. C., Janda, M., } \\
\text { Webb, P. M., Obermair, A., Eakin, E. } \\
\text { G., . . Beesley, V. L. (2011). Safety, fea- } \\
\text { sibility and effects of an individualised } \\
\text { walking intervention for women under- } \\
\text { going chemotherapy for ovarian cancer: } \\
\text { a pilot study. BMC Cancer, 11, 389- } \\
\text { 389. doi:10.1186/1471-2407-11-389 }\end{array}$ & Australia & $\begin{array}{l}\text { To assess safety, feasibility, } \\
\text { and impact of an inter- } \\
\text { vention in women with } \\
\text { ovarian cancer undergo- } \\
\text { ing chemotherapy. }\end{array}$ & $\begin{array}{l}\text { Experimen- } \\
\text { tal study } \\
\text { without ran- } \\
\text { domization } \\
\text { or control } \\
\text { group }\end{array}$ & $\begin{array}{l}\text { Ovarian } \\
\text { cancer } \\
\quad 17 \\
\text { intervention } \\
\text { group }\end{array}$ \\
\hline S12 & $\begin{array}{l}\text { Swenson, K., Nissen, M. J., \& Henly, } \\
\text { S.(2010). Physical activity in women re- } \\
\text { ceiving chemotherapy for breast cancer: } \\
\text { adherence to a walking intervention. } \\
\text { Oncology Nursing Forum, 37(3), 321- } \\
\text { 330. doi:10.1188/10.ONF.321-330 }\end{array}$ & $\begin{array}{l}\text { USA- } \\
\text { Minnesota }\end{array}$ & $\begin{array}{l}\text { To describe and predict } \\
\text { adherence to a physical } \\
\text { activity protocol for pa- } \\
\text { tients with breast cancer } \\
\text { receiving chemotherapy. }\end{array}$ & $\begin{array}{l}\text { Experimen- } \\
\text { tal study } \\
\text { with ran- } \\
\text { domization } \\
\text { without con- } \\
\text { trol group }\end{array}$ & $\begin{array}{c}\text { Brest cancer } \\
29 \\
\text { intervention } \\
\text { group }\end{array}$ \\
\hline
\end{tabular}

As a result of the critical analysis of the studies included in this review, and in the light of the existing theoretical knowledge, five thematic areas emerged: duration, frequency, and monitoring of walking during chemotherapy; adherence to the walking intervention; effects on psychological and physical symptoms; target population; and assessment tools.

\section{Duration, frequency, and monitoring of walking during chemotherapy}

Walking is the most commonly used physical activity intervention (Husebø et al., 2015; Naraphong, Lane, Schafer, Whitmer, \& Wilson, 2015; Sung \& Bae, 2012); it is easy to implement and considered the exercise of choice in several studies (Sung \& Bae, 2012; Szymlek-Gay, Richards, \& Egan, 2011). The studies revealed heterogeneity concerning the application of the walking intervention, namely in terms of its duration, intensity, frequency, supervision, and assessment tools, which hampered comparison. Lewis, Lyons, Jarvis, and Baillargeon (2015) reported the same difficulty in a review about physical activity monitoring. The duration of the walking intervention often overlapped with the period of time of chemotherapy cycles. The most common duration was 12 weeks (S2, S3, S5, S7, S9, S10), followed by shorter interventions between 9 and 12 weeks (S6, S8) and interventions with monitoring beyond the chemotherapy cycles, up to 6 months (S1, S4, S12).

Interventions were mostly of moderate intensity and, in some studies, of progressive intensity (S2, S3, S5). Gokal et al. (2016) recommended that participants began by completing 10 minutes of walking and then increased the duration of walking to $30 \mathrm{~min}$ utes five times a week. Naraphong et al. (2015) recommended 20 minutes of walking per session or, at least, two 10-minute sessions until a maximum of 20-30 minutes, three to five times per week. On the other hand, Huang et al. (2015) describe a program of progressive increase of exercise prescription through three stages: initial, improvement, and maintenance. The suggested exercise frequency was three times/week for the first 6 weeks and five times/ week for the second 6 weeks. Exercise duration was also increased gradually, from $15-25 \mathrm{~min} /$ session for weeks 1 to 4 , to $25-35 \mathrm{~min} / \mathrm{session}$ for weeks 5 to 8 , and $35-40 \mathrm{~min} /$ session for weeks 9 to 12 . In other studies, the intervention was progressive according to the participants' cardiorespiratory capacity $(\mathrm{S} 6, \mathrm{~S} 7)$ or with individualized prescriptions (S11).

One of the strategies used in two studies was the 10,000 steps $(S 8, S 12)$. People have been advised to walk more than 10,000 steps per day with the purpose of promoting health 
(Castres, Tourny, Lemaitre, \& Coquart, 2017). This intervention is considered a moderate physical activity, which takes place on average over 30 minutes (Backman et al., 2014). The origins of the 10,000-steps recommendation are not exactly scientific because the pedometers sold in Japan in the 1960s were marketed under the name Manpo-kei, which means 10,000 steps meter, and have been used in several studies related to health promotion over the past few years (Castres et al., 2017; Backman et al., 2014; Swenson, Nissen, \& Henly, 2010; Bravata et al., 2007). This intervention is usually associated with the use of the pedometer or the step diary. Bravata et al. (2007) reported that the use of a monitoring system can be an essential factor for motivating physical activity. Pedometers were used in five studies (S1, S2, S3, S8, S12), in combination with the dairy $(\mathrm{S} 1, \mathrm{~S} 2, \mathrm{~S} 8)$ or only the diary $(S 4, S 9, S 11)$. Adherence to the interventions using Internet diaries, pedometers, and handheld personal digital assistants was greater than the adherence to the traditional paper diaries (Lewis et al., 2015). Pedometers can be used in these studies both as an intervention to encourage physical activity and as a tool to measure the number of steps per day. Participants may have increased their physical activity just by knowing that they were being monitored (Bravata et al., 2007). The use of pedometers while walking allows for physical activity self-management, being a more cost-effective method than other intervention strategies (Johnson, Lier, Soprovich, Mundt, \& Johnson, 2015). Self-managed interventions, without the need for individualized, supervised sessions which require specialist input or additional support from health professionals, with high costs, have obtained positive results, confirming their effectiveness (Gokal et al., 2016). Most of the programs in this review were self-managed at home (S1, S2, S3, S4, S9, S10, S12). Backman et al. (2014) included a weekly group walk in their study. On the other hand, in the study conducted by Naraphong et al. (2015), a family member was invited as a coach to help the participant identify appropriate and safe activities, which could represent a source of motivation. According to Yang, Tsai, Huang, and Lin (2011), the effectiveness of a home-based exercise intervention during cancer treatment depends greatly on the motivation of participants to adhere to this program.

\section{Adherence to the walking intervention}

As previously mentioned, the studies under analysis had several objectives, which is reflected in the assessment tools and, consequently, in outcome assessment. In addition, the studies use different methods, which leads to variations in effect size estimates. Some studies aimed to assess adherence to the intervention (S1, S5, S8, S11). In a study conducted by Vallance et al. (2016), contrary to their hypothesis, the structured physical activity resource kit did not facilitate the physical activity adherence behavior compared with standard health print materials among women with breast cancer. According to Huang et al. (2015), exercise time and intensity influence adherence to the walking-exercise program. The predictors of adherence for time were fatigue and interest in exercise, and the predictors of adherence for intensity were fatigue and perceived importance of exercise. Backman et al. (2014) reported that the majority of the participants achieved an average of $83 \%$ of the target of 10,000 steps per day, with the intervention group achieving a significant increase in their daily physical activity $(p=0.016)$. Swenson et al. (2010) concluded that the adherence to a regular physical activity program was difficult to maintain during chemotherapy, but improved with each treatment cycle and after chemotherapy completion. Adherence is a complex phenomenon that encompasses factors related to each patient's health, condition, treatment, and environment, as well as psychological factors, all of which influence patient adherence to the prescribed program (Husebø, Dyrstad, Søreide, \& Bru, 2013). With regard to the adherence to the interventions in the studies under analysis, it ranged from 74 to $95 \%$. Adherence varied significantly in previous studies of home-based exercise programs with cancer patients (Husebø et al., 2013; Newton et al., 2011). Swenson et al. (2010) reported that adherence was less than ideal among the patients who completed the study, with an average of less than $75 \%$ of the steps prescribed during the first 6 weeks. 
However, after treatment completion, adherence increased to $87 \%-98 \%$ at 3, 6, 9, and 12 months. According to Newton et al. (2011), adherence rates may have been related to the close monitoring, personalized feedback or ongoing support, and the nature of the interventions, allowing the participants to undertake sessions at times most convenient to them. In addition, and in comparison with other types of interventions, walking is reported to be the preferred type of exercise.

\section{Effects on physical and psychological symptoms}

The included studies assessed both the physical (S2, S3, S4, S6, S7, S9, S11) and the psychological symptoms (S2, S3, S4, S10, S11) of the intervention. S6 and S9 reported effects of the intervention in improving cardiorespiratory capacity but found no association with fatigue. Kim, Shin, and Suk (2015) reported significant reductions in weight, body mass index, and percent body fat. However, the immune cell counts did not change significantly. Yang et al. (2011) and Newton et al. (2011) reported significantly lower results in the severity of physical symptoms. Gokal et al. (2016) showed significant positive effects on fatigue, self-esteem, and overall mood. However, no effects were found for anxiety and depression. Naraphong et al. (2015) reported that the intervention group showed significant improvement in physical fitness, less fatigue (albeit with low statistical significance), and a significant reduction in mood disturbance, but not strong enough to decrease sleep disturbance. The impact on mood disorders was reported in S2, S3, and S10. Lastly, Husebø et al. (2015) underlined feelings of psychological, physical, and social well-being associated with walking, as well as the fact that the participants reported feeling stronger from a psychological point of view after exercising.

The impact of walking on the outcome measures analyzed in this study is very heterogeneous. However, the scientific evidence describes the impact of physical activity on cancer patients, highlighting the importance of encouraging them to adopt active lifestyles during treatment and throughout the survival period (Zhang, Xiao, \& Chen, 2017; Gokal et al., 2016; Zimmer et al., 2016; Husebø et al., 2015; Jacobsen et al., 2007), particularly through walking (Lewis et al., 2015). In fact, a low-intensity physical activity intervention in the form of walking is feasible during chemotherapy treatment. Among the existing physical activities, walking is a feasible alternative, despite increasing symptoms associated with chemotherapy (Backman et al., 2014).

\section{Target population}

Some recommendations emerged from this review, both for future research and the implementation of these strategies in health care settings. As regards research and, more specifically, the methodological choices in these studies, it can be concluded that the walking intervention was implemented very differently, namely in terms of duration, intensity, frequency, and monitoring. On the other hand, the majority of the studies under analysis was conducted with breast cancer patients, preventing the generalization to other populations. Vallance et al. (2016) underlined that the trajectory of the patient with breast cancer presents a unique set of challenges that significantly impacts their ability and willingness to adopt a physical activity program.

On the other hand, the study population was predominantly female, with only eight male participants (one participant in S9 and seven participants in S8). Some of the clinical trials used very small samples, an aspect which was considered a limitation by the authors themselves (S1, S3, S6, S8, S10).

\section{Assessment tools}

Outcome assessment tools varied significantly, including the use of physical activity self-reports (S4, S5, S9, S10). According to Backman et al. (2014), the reliance on self-reported data hampers the possibility of knowing if the data are accurate due to the lack of control of the reported steps. Lewis et al. (2015) emphasized that physical activity interventions have evolved from behavioral interventions with paper diaries into new technologies, facilitating monitoring. Technology shows promise as a new intervention modality. Pedometer monitoring can, in itself, be an intervention. Indeed, the use of these small and relatively inexpensive devic- 
es is associated with significant increases in physical activity and improvements in health status (Bravata et al., 2007). Goode, Lawler, Brakenridge, Reeves, and Eakin (2015), in a systematic review on telephone, print, and Web-based interventions for physical activity, diet, and weight control among cancer survivors, suggest the integration of other technologies such as SMS and mobile/smartphone applications. This includes exploration of the potential of these technologies to deliver long-term support in a more cost-effective way. Lewis et al. (2015) reported that many of these systems allow researchers and participants to conduct daily surveillance of their app use (amount of daily activity) and get involved with others (participants' chat). They would allow engagement with additional app functions (i.e., monitoring other health indicators, creating smart alarms, turning on notifications), which may provide more detailed information and individualized recommendations by health professionals. Further research is required in this area.

To sum up, the results suggest that nurses should introduce interventions such as walking in their practices, as well as encourage people with cancer to participate in them (Naraphong et al., 2015). In the studies under analysis, the walking intervention had different characteristics, particularly in terms of duration, frequency, intensity, and monitoring. Gokal et al. (2016) reported that self-managed interventions have many advantages, including the fact that they can be performed at home at any time, have a lowcost design, and require no face-to-face contact, guidance throughout the intervention or any exercise equipment.

With regard to the implications for nursing, it is important to continue developing research on the assessment of the type, duration, and intensity of walking, as well as on the trajectories of patient symptoms during chemotherapy, which will contribute to developing individualized nursing interventions (Naraphong et al., 2015; Swenson et al., 2010). Nurses should integrate these interventions into their clinical practice and motivate patients to participate in physical activity programs while paying more attention to the meaning of extrinsic motivation factors and how they can be applied clinically in health behavior change programs (Husebø et al., 2015). Physical activity interventions should be adapted to the cycle of chemotherapy treatment, and users should be informed that their ability to participate in physical activity will improve over time and that they should not be discouraged if they experience any difficulties in maintaining their normal physical activity for several days after the chemotherapy treatments (Swenson et al., 2010).

\section{Conclusion}

Through the analysis of the studies based on the objectives set out, it was possible to identify the scientific evidence published on the use of walking as an intervention for patients undergoing chemotherapy. The scientific evidence found is still limited to a very specific population which is mostly composed of women with breast cancer. Further studies should be conducted to understand the correlations between some variables, namely the impact of the walking intervention on symptoms, by including clinical trials with more representative samples and standardized assessment tools with the purpose of improving the analytical approaches to identifying evidence-based interventions. Walking programs need to take into account the needs of the target population in order to optimize adherence, outcomes, and behavior changes. The low-intensity physical activity intervention in the form of walking is feasible during chemotherapy treatment. Despite the increasing symptoms, walking seems to be a viable alternative in terms of the degree of difficulty. Providing patients with the ability to self-manage their own exercise schedules is less expensive and can be introduced on a large scale. At this level, it would be important to develop walking monitoring tools using the pedometer in mobile/smartphone applications, as well as to assess their use in future studies. With regard to the implications of this study for nursing practice, it can be concluded that nurses should include strategies to improve physical activity behaviors and reduce the sedentary time during adjuvant chemotherapy. It is important to communicate the ben- 
efits of walking with the purpose of inspiring and motivating patients throughout their disease trajectory. As regards research, this study draws attention to the need for developing more research focused on specific exercises such as walking, using reliable instruments and seeking common outcomes.

\section{References}

Bennion, A., \& Molassiotis, A. (2013). Qualitative research into the symptom experiences of adult cancer patients after treatments: A systematic review and meta-synthesis. Supportive Care in Cancer, 21(1), 9-25. doi:10.1007/s00520-012-1573-x

Bravata, D. M., Smith-Spangler, C., Sundaram, V., Gienger, A. L., Lin, N., Lewis, R., ... Sirard, J. R. (2007). Using pedometers to increase physical activity and improve health: A systematic review. Journal of the American Medical Association, 298(19), 22962304. doi:10.1001/jama.298.19.2296

Bray, F. (2016). The evolving scale and profile of cancer worldwide: Much ado about everything. Cancer Epidemiology Biomarkers and Prevention, 25(1), 3-5. doi:10.1158/1055-9965.EPI-15-1109

Castres, I., Tourny, C., Lemaitre, F., \& Coquart, J. (2017). Impact of a walking program of 10,000 steps per day and dietary counseling on health-related quality of life, energy expenditure and anthropometric parameters in obese subjects. Journal of Endocrinological Investigation, 40(2), 135-141. doi:10.1007/s40618-016-0530-9

Coolbrandt, A., Wildiers, H., Aertgeerts, B., Van der Elst, E., Laenen, A., Dierckx de Casterlé, B., ... Milisen, K. (2014). Characteristics and effectiveness of complex nursing interventions aimed at reducing symptom burden in adult patients treated with chemotherapy: A systematic review of randomized controlled trials. International Journal of Nursing Studies, 51(3), 495-510. doi:10.1016/j. ijnurstu.2013.08.008

Goode, A. D., Lawler, S. P., Brakenridge, C. L., Reeves, M. M., \& Eakin, E. G. (2015). Telephone, print, and web-based interventions for physical activity, diet, and weight control among cancer survivors: A systematic review. Journal of Cancer Survivorship, 9(4), 660-682. doi:10.1007/s11764-015-0442-2

Husebø, A. M., Dyrstad, S. M., Søreide, J. A., \& Bru, E. (2013). Predicting exercise adherence in cancer patients and survivors: A systematic review and meta-analysis of motivational and behavioural factors. Journal of Clinical Nursing, 22(1-2), 4-21. doi:10.1111/j.1365-2702.2012.04322.x

Jacobsen, P. B., Donovan, K. A., Vadaparampil, S. T., \& Small, B. J. (2007). Systematic review and meta-analysis of psychological and activity-based interventions for cancer-related fatigue. Health Psychology, 26(6), 660-667. doi:10.1037/02786133.26.6.660

Joanna Briggs Institute. (2014). Joanna Briggs Institute reviewers manual: Methodology for JBI mixed methods systematic reviews. Adelaide, Australia: Author. Retrieved from https://joannabriggs.org/assets/ docs/sumari/ReviewersManual_Mixed-MethodsReview-Methods-2014-ch1.pdf

Johnson, S. T., Lier, D. A., Soprovich, A., Mundt, C., \& Johnson, J. A. (2015). How much will we pay to increase steps per day? Examining the cost-effectiveness of a pedometer-based lifestyle program in primary care. Preventive Medicine Reports, 2, 645 650. doi:10.1016/j.pmedr.2015.08.001

Lewis, Z. H., Lyons, E. J., Jarvis, J. M., \& Baillargeon, J. (2015). Using an electronic activity monitor system as an intervention modality: A systematic review health behavior, health promotion and society. BMC Public Health, 15(585), 2-15 doi:10.1186/ s12889-015-1947-3

Meneses-Echávez, J. F., González-Jiménez, E., Correa-Bautista, J. E., Río, J., \& Ramírez-Vélez, R. (2015). Efectividad del ejercicio físico en la fatiga de pacientes con cáncer durante el tratamiento activo: Revisión sistemática y metaanálisis. Cadernos de Saúde Pública, 31(4), 667-681. doi:10.1590/ 0102-311X00114414

Peixoto, T. M., Peixoto, N. M., Santos, C., \& Pinto, C. (2016). Estratégias de autogestão da fadiga nos sobreviventes de cancro: Revisão sistemática da literatura. Revista de Enfermagem Referência, 4(10), 113-123. doi:10.12707/RIV16023

Sasaki, H., Tamura, K., Naito, Y., Ogata, K., Mogi, A., Tanaka, T., ... Takamatsu, Y. (2017). Patient perceptions of symptoms and concerns during cancer chemotherapy: 'Affects my family' is the most important. International Journal of Clinical Oncology, 22(4), 793-800. doi:10.1007/s10147-017-1117-y

Siegel, R., Desantis, C., Virgo, K., Stein, K., Mariotto, A., Smith, T., ... Ward, E. (2012). Cancer treatment and survivorship statistics, 2012. CA Cancer Journal for Clinicians, 62(4), 220-241. doi:10.3322/ caac. 21149

Sung, K., \& Bae, S. (2012). Effects of a regular walking exercise program on behavioral and biochemical aspects in elderly people with type II diabe- 
tes. Nursing and Health Sciences, 14(4), 438-445. doi:10.1111/j.1442-2018.2012.00690.x

Szymlek-Gay, E. A., Richards, R., \& Egan, R. (2011). Physical activity among cancer survivors: A literature review. New Zealand Medical Journal, 124(1337), 77-89. Retrieved from https://www. nzma.org.nz/journal/read-the-journal/all-issues/2010-2019/2011/vol-124-no-1337/article-szymlek-gay

Wagland, R., Richardson, A., Armes, J., Hankins, M., Lennan, E., \& Griffiths, P. (2015). Treatment-related problems experienced by cancer patients undergoing chemotherapy: A scoping review. Eu- ropean Journal of Cancer Care, 24(5), 605-617. doi:10.1111/ecc.12246

Zhang, X., Xiao, H., \& Chen, Y. (2017). Effects of life review on mental health and well-being among cancer patients: A systematic review. International Journal of Nursing Studies, 74, 138-148. doi:10.1016/j. ijnurstu.2017.06.012

Zimmer, P., Baumann, F. T., Oberste, M., Wright, P., Garthe, A., Schenk, A., ... Wolf, F. (2016). Effects of exercise interventions and physical activity behavior on cancer related cognitive impairments:systematic review. BioMed Research International, 2016(1820954). doi:10.1155/2016/1820954 
